OPEN ACCESS

Edited by:

Hollie Smith,

University of Rhode Island,

United States

Reviewed by:

Karen M. Taylor,

University of Alaska Fairbanks,

United States

James G. Cantrill,

Northern Michigan University,

United States

*Correspondence:

Brianne Suldovsky

brianne.suldovsky@pdx.edu

Specialty section:

This article was submitted to Science and Environmental

Communication,

a section of the journa

Frontiers in Communication

Received: 10 November 2017

Accepted: 14 March 2018

Published: 29 March 2018

Citation:

Suldovsky B, Arbor E, Skillin V and Lindenfeld L (2018) Communicating

Environmental Risks: Local

Newspaper Coverage of Shellfish

Bacterial Contamination in Maine.

Front. Commun. 3:12.

doi: $10.3389 /$ fcomm.2018.00012

\section{Communicating Environmental Risks: Local Newspaper Coverage of Shellfish Bacterial Contamination in Maine}

\author{
Brianne Suldovsky ${ }^{1 *}$, Eva Arbor ${ }^{2}$, Victoria Skillin $^{3}$ and Laura Lindenfeld ${ }^{4}$ \\ ${ }^{1}$ Department of Communication, Portland State University, Portland, OR, United States, ${ }^{2}$ Public Program and Event \\ Facilitator, Maine Discovery Museum, Bangor, ME, United States, ${ }^{3}$ Information Technology Auditor, Unum, Portland, ME, \\ United States, ${ }^{4}$ Alan Alda Center for Communicating Science, Melville Library, Stony Brook University, Stony Brook, NY, \\ United States
}

Coastal resources play a vital role in Maine's cultural and economic wellbeing, contributing an estimated 168 billion dollars to the Maine economy. There are numerous risks to the sustainability of Maine's shellfishing industry and working waterfront, including pathogenic bacterial pollution. In this study, we ask a broad fundamental question central to science and environmental journalism: how do newspapers cover localized environmental risks and what are the implications of those approaches? Utilizing the northeastern US state of Maine's shellfishing industry as an exemplar environmental issue, this study examines how Maine's two most read newspapers, the Bangor Daily News and the Portland Press Herald, report on bacterial contamination and shellfish. This study examines the themes that are present in the newspaper articles published about shellfish between 2003 and 2014 and analyses the types of sources journalists used within their coverage of these issues. Overall, we identified seven key themes: economic concerns, environmental impacts, political and regulatory issues, issues of public health and safety, reference to cultural values, technical and infrastructural issues, and aesthetic concerns. The most commonly cited individuals in the articles were government officials and scientists. The least cited groups were clammers and shellfishermen, general citizens, advocacy groups, and worm diggers. Implications for local coverage of environmental risks in Maine, science communication, and sustainability science are discussed.

Keywords: environmental risk, shellfish, Maine, newspaper, expertise

\section{INTRODUCTION}

Coastal resources play a vital role in Maine's cultural (McCay and Acheson, 1990; Ednie et al., 2010) and economic (Colgan, 2004) wellbeing. Aquaculture alone contributes over 100 million dollars to the Maine economy (Cole et al., 2016), and estimates of the working waterfront as a whole are up to 168 million dollars (Colgan, 2004). Unfortunately, there are numerous threats to the sustainability of Maine's shellfishing industry and working waterfront. One of the primary threats is pathogenic bacterial pollution (Maine Department of Marine Resources, 2017). According to the Maine Department of Marine Resources (2017), the vast majority of shellfish flats are closed at any given time due to point source and non-point source bacterial contamination. These closures threaten the economic stability of the working waterfront and shellfishing industry and bacterial contamination 
represents a significant public health risk to beachgoers (Maine Healthy Beaches, 2013). Improving testing and prediction processes for pollution events while gaining a better understanding of the social and ecosystem dynamics that produce such events is paramount to reducing instances of closure and protecting public health.

Maintaining the safety of shellfish and grappling with issues such as microbial contamination is commonplace for shellfish resource managers and policy makers (Shumway and Rodrick, 2009), and there is evidence that bacterial contamination rates is on a steady incline (Elston et al., 2008). While shifts in the ecosystem, including warming ocean temperatures (Vezzulli et al., 2012), play a role in the increasing presence of bacterial contaminants, so, too, does human activity and the built human environment. For fecal coliform bacteria in particular, increases in human population and the conversion of natural landscapes to build environments (e.g., roads and sidewalks) are significant contributors to the increase in bacterial contamination (Mallin et al., 2001).

To ensure the sustainability of Maine's coastal resources, researchers at the University of Maine and the University of New Hampshire created a consortium of scholars, regulators, and institutions called the New England Sustainability Consortium (NEST).NEST's Safe Beaches and Shellfish Project ${ }^{1}$, the first project implemented through the consortium, was a three-year research project aimed at strengthening the scientific basis for decisionmaking surrounding pathogenic bacterial contamination within Maine and New Hampshire's beaches and shellfish flats. The goals of the Safe Beaches and Shellfish Project included gaining a better understanding of the relationship between biophysical conditions (e.g., rainfall events, topography, etc.) and pathogenic bacterial contamination, improving testing procedures for detecting pathogens, improving the capacity to predict pollution events, and understanding the social dimensions of beach and shellfish flat management, closures, and public communication. Mass communication research can aid sustainability science endeavors such as NEST's Safe Beaches and Shellfish Project (Smith et al., 2016). This study was conducted as a part of the Safe Beaches and Shellfish Project to gain insight into the media landscape surrounding shellfish bacterial contamination in Maine.

\section{News Media and Environmental Risks}

News media play an important role in negotiating public engagement with environmental risks (Allan et al., 2000). Previous literature has demonstrated, for example, the role of mass media in communicating with the public about climate change (Bell, 1994; Sampei and Aoyagi-Usui, 2009; Boykoff, 2011), pollution events (Ader, 1995), natural disasters (Spence et al., 2007), and biotechnology (Nisbet and Lewenstein, 2002). Media coverage has also been found to influence public perception of risks. Coleman (1993) found that mass media communication influences societal-level and individual level risk judgments. Research on information seeking has generally found that local media outlets in particular play a key role in communicating with the

${ }^{1}$ See http://www.newenglandsustainabilityconsortium.org/ for more information (Accessed: September 1, 2017). public about risks to the environment and public health, even with the availability of alternative information sources (Wakefield and Elliott, 2003). Previous studies also show that local news organizations are generally the most trusted news sources (Mitchell et al., 2016).

In this study, we focus exclusively on newspaper coverage of shellfish and bacterial contamination. We chose to focus on newspaper coverage of issues related to shellfish and bacterial contamination for three reasons. First, previous research has highlighted the continued use of newspapers as sources information for US adults (Gallup, 2017), particularly for news about environmental risks (McCallum et al., 1991; Wakefield and Elliott, 2003). Second, there is evidence that newspapers may provide a better measure of media coverage of risks than televised coverage, particularly when the environmental risk in question is chronic and localized (Driedger, 2007). Third, some evidence suggests that public concern about environmental risks is, in part, influenced by newspaper coverage (Sampei and Aoyagi-Usui, 2009). We are interested in how local print newspaper outlets in Maine communicate about shellfish and bacterial contamination along the coast and the potential implications of that communication for public understanding of science and the environment.

Research Question \#1: How Do Newspapers in Maine Cover Issues Related to Shellfish Bacterial Contamination?

\section{Media and Communicating Expertise}

Beyond communicating with the public about environmental risks, news media also signal to the public whose opinion matters regarding those risks (Allan et al., 2000). This means that the news media determine who counts as an expert (Allan et al., 2000). Expertise is tightly connected to cultural authority, where those who are assumed to be more competent and knowledgeable are designated experts (Wayland, 2003) and have higher statuses (Bunderson and Barton, 2010). In turn, those with higher statuses have an easier time convincing others of their expertise (Kuhn and Rennstam, 2016). Although expertise is, to some extent, autonomous and not subject to the opinion of others, it is also ascribed (i.e., a characteristic afforded to an individual or organization by relevant others) (Kuhn and Rennstam, 2016). In this vein, many scholars argue that expertise is fundamentally a communication phenomenon (Huckfeldt, 2001; Bunderson and Barton, 2010; Carr, 2010; Treem, 2012; Kuhn and Rennstam, 2016; Treem and Leonardi, 2016). For the purposes of the current study, we understand expertise as a claim or attribution of knowledgeability that manifests through communication (Kuhn and Rennstam, 2016). We do not use the term "expertise" to mean that media coverage insinuates specialized knowledge of a topic through mere citation nor that media citations establish actual source credibility.

Issues of expertise are of central concern for public understanding of science. Previous work in science communication has explored, for example, representations of sociolinguistic expertise in the media (Jaspers, 2014), how non-governmental organizations use scientific expertise (Morton et al., 2002), and 
the extent to which scientists view themselves as experts when communicating with the public (Horst, 2013). Representations of scientific expertise in relation to environmental risks are not a given nor are always consistent. Griffin and Dunwoody (1997) found that news outlets that serve smaller communities are less likely than news outlets that serve larger communities to interpret environmental pollution from a scientific perspective (Griffin and Dunwoody, 1997). What's more, Greenberg et al. (1989) found that government, industry, and citizens account for the majority of sources cited by major news networks in relation to environmental risks, while experts and spokespersons for environmental advocacy groups were used much less often.

The role of the media in communicating expertise is substantial, and there is a lack of uniformity regarding how scientific expertise is utilized in media coverage of environmental risks. Therefore, understanding how scientists and others are cited in media coverage of environmental risks is a fundamental part of understanding linkages between media communication and public understanding of science. Specifically, who is being cited-that is, whose opinion is given an attribution of knowledgeability via media communication-in localized news coverage of bacterial contamination and shellfish in Maine has implications for science communication, public understanding of environmental risks, and media coverage of science. As such, our second research question is:

Research question \#2: What individuals or groups are used as sources within newspaper coverage of shellfish bacterial contamination?

\section{MATERIALS AND METHODS}

\section{Data}

We conducted a conventional content analysis (Hsieh and Shannon, 2005) of Maine's two most read newspapers (the Bangor Daily News and Portland Press Herald) to explore local news content and expertise surrounding shellfish bacterial contamination in Maine. Articles published between 2003 and 2014 were included for this analysis (See Table 1). Articles were collected using the LexisNexis Academic database using the search terms shellfish, clam flat, and shellfish + bacteria. We chose these terms in an effort to capture news coverage of shellfish in general ("shellfish" and "clam flat") and specifically hone in on articles that combined discussions of shellfish and bacterial contamination ("shellfish" + "bacteria") without capturing articles that included the word "bacteria" but were not discussing shellfish. These terms yielded approximately 2,500 news articles. Articles were arranged according to search term and date of publication, so that articles resulting from each search term were listed in reverse chronological order. This produced three lists. To make the data set more manageable, a random sample of every fourth article from each list $(n=850)$ and the entire set of articles from $2014(n=154)$ were included for analysis, providing a total of 1,004 news articles (See Table 1). We chose to analyze the entire set of the articles published in 2014 to get a better sense of the current local news landscape and to feedback that information to NEST researchers.
TABLE 1 | Number of newspaper articles-by source and date.

\begin{tabular}{lccr}
\hline Publication & $\begin{array}{c}\text { Number of articles } \\
\text { 2003-2013 } \\
\text { (random sample) }\end{array}$ & $\begin{array}{c}\text { Number of } \\
\text { articles } \\
\mathbf{2 0 1 3 - 2 0 1 4}\end{array}$ & Total \\
\hline Bangor Daily News & 615 & 43 & 658 \\
Portland Press Herald & 235 & 111 & 346 \\
\hline Total & 850 & 154 & 1,004 \\
\hline
\end{tabular}

Articles were coded separately by three different researches using NVivo 10 software for Mac.

\section{Thematic Content Analysis}

A thematic codebook was built based on a review of a random sample of 50 newspaper articles. Themes that emerged within the data included the following: the physical appearance of coastal resources (labeled "esthetics"), the importance of shellfish for Maine's way of life (labeled "culture"), monetary aspects of the shellfishing industry (labeled "economics"), the environment and ecosystems (labeled "environmental"), the impact of bacterial contamination on public health (labeled "public health and safety"), issues surrounding regulation of shellfishing resources and other political aspects of shellfish management (labeled "political"), and infrastructural issues central to shellfish management and pollution events (labeled "technical"). Importantly, these themes are not mutually exclusive and would often overlap. For example, many newspaper articles that discussed the technical aspects of shellfish management would also discuss the environmental impacts of contamination.

Themes were coded at the article level. Because the authors were primarily concerned with understanding the breadth of themes that occur when shellfishing issues are covered in newsprint, articles could be coded with more than one theme if multiple themes emerged within the text. For example, if a news article discussed the economic ramifications of a new regulatory practice, the article would be coded as both economic and political. Due to limitations of the NVivo for the Mac system at the time this study was conducted, it was not possible to run reliability statistics in NVivo to assess intercoder reliability. To compensate for this, all three coders coded the entire set of 1,004 news articles. To ensure that we were coding consistently, we completed a manual reliability check early on in our coding process using a random sample $(n=70)$ of the coded articles. An initial reliability test showed, out of the 70 selected articles, a coding consistency across all frames of $87 \%$. In addition to the manual reliability test at the beginning of the coding process, the authors of this study reviewed all of the coded materials in NVivo after the coding was complete for each of the three coders. Any discrepancies or disagreements regarding assigned codes were discussed and resolved.

\section{Expertise Analysis}

Newspaper articles were also examined for the sources reporters included within their articles. After compiling a list of the individuals included within the news articles, sources were grouped into the following categories: advocacy groups, shell-fishermen, government agencies and representatives, non-governmental 
organizations, scientists, commercial interests (i.e., business owners), worm diggers, and unaffiliated individual citizens. Sources were then coded with these category names based on how the author of the news article characterized the source. Importantly, they were not coded based on the actual credentials of the source. For example, if a reporter quoted researcher Jane Smith and labeled her as a member of Maine's Department of Marine Resources (a government agency), her quote would be coded as government agency, even if she also works as a scientist at the Maine Department of Marine Resources. Additionally, if a source was labeled using more than one category (e.g., a scientist at a government agency), they were coded twice, once for each category. Expertise was coded at the instance level, from the time a source was mentioned or quoted to the time the journalist turned to another topic or source. As such, a code could consist of one sentence or it could be an entire paragraph. Coding consistency was not a concern regarding the expertise codes, as no researcher interpretation was required to code this information. As such, consistency checks for expertise codes were not conducted.

We assume for the purposes of this study that the mere presence of a statement from a particular source within a news article communicates "expertise" relevant to the topic being covered. That is, it was not necessary for journalists to label the sources they use and quote as an expert; rather, the mere presence of external sources in news coverage is arguably sufficient to signal topical expertise.

\section{RESULTS}

\section{RQ1: How Do Newspapers in Maine Cover Issues Related to Shellfish Bacterial Contamination?}

The most common themes in the sampled newspaper articles were economic, environmental, political, and public health and safety. The least common themes were cultural, technical, and esthetic. See Figure 1 for a comparison of frame occurrence rates. Articles that had an economic theme $(n=447)$ generally referenced the amount of money the shellfishing industry brings into the state or the amount of money lost over closed clam flats. For example, one article stated: "John Lyon, 54, of Scarborough, a commercial digger for about 40 years, estimated he lost $\$ 20,000$ in income last year." Articles that included an environmental theme $(n=412)$ tended to focus on the ecosystem dynamics of shellfish beds and clam flats (e.g., the impact of invasive species on shellfish habitat), including the impacts of environmental pollutants. Articles that included a political theme $(n=331)$ focused on issues such as current regulatory practices and, often, disagreements over those practices, whether they were between lawmakers from different political parties or between lawmakers and users of coastal resources. For example, one article stated: "Clam diggers and their supporters turned out in force at the State House on Wednesday to urge a review of Maine's water quality testing program for shellfish.” Finally, articles that

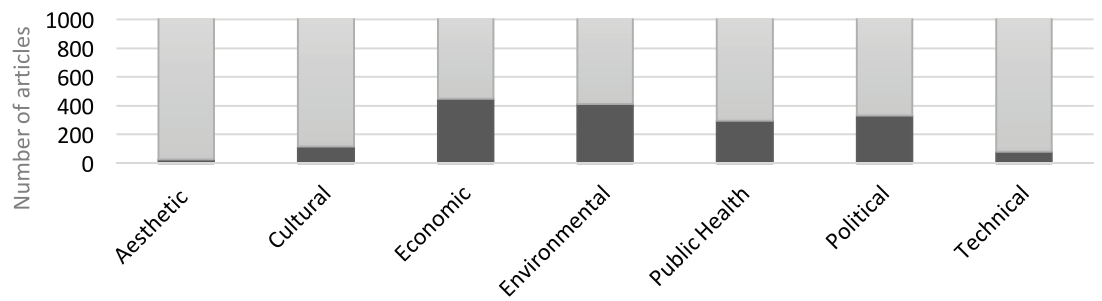

FIGURE 1 | Media themes.

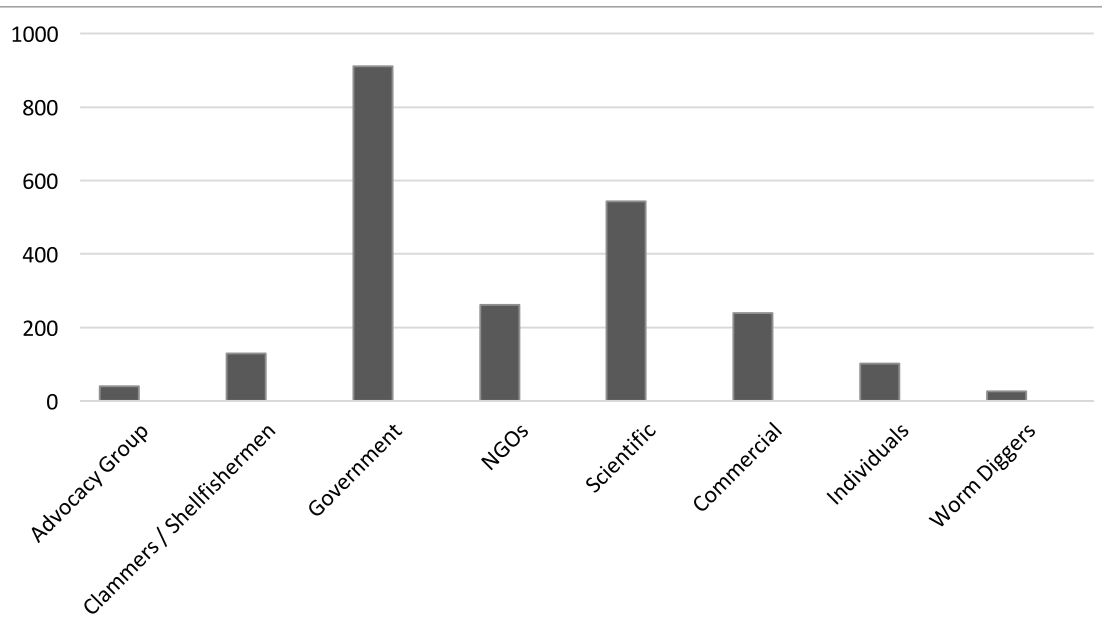

FIGURE 2 | Expertise. 
included a public health and safety theme $(n=298)$ tended to focus on the role of public health in ensuring the future of shellfish as a resource and the complexity of balancing public health with other concerns. For example, one article, while discussing contamination along Maine's coast, stated: "Maine clams command a good price only as long as they're clean and safe. Public health must not be compromised for the sake of expediency."

Articles that included a cultural theme $(n=115)$ tended to focus on shellfish as a way of life, deeply tied to the history of Maine and central to what it means to be a Mainer. For example, in an announcement of a new cookbook, one article connected seafood to Maine history: "In September, the 47-year-old company that has fed generations of Mainers and countless tourists oysters, mussels and other fresh delights from the sea launched its first book... [that is] more a history of a working-class Portland family that stays successful by staying honest." Articles that included a technical theme $(n=82)$ were somewhat rare. These articles focused on infrastructural issues and updates (or lack thereof) of technology and primarily focused on the connection between poor infrastructure and bacterial contamination. For example, one article explained: "Scientists expect a round of testing this week to show that water quality is improving in the Mousam River because of recent upgrades at the town's wastewater treatment plant." Finally, the least present theme in news coverage of shellfish and bacterial contamination was esthetic $(n=28)$. The emergence of this theme tended to occur in more casual articles about experiencing the Maine coast. For example, in a discussion of touring Maine's coastal resources, one article referenced that the "scenery is terrific."

\section{RQ2: What Experts Are Cited Within Media Coverage in Relation to Shellfishing Issues?}

The most common sources included in newspaper coverage of shellfish-related issues were representatives from government agencies ( $n=911$ instances) followed by scientists ( $n=544)$, nongovernmental organizations $(n=262)$, and commercial interests or businesses $(n=240)$. The least commonly cited sources were clammers and shell fishermen $(n=130)$, individual citizens $(n=102)$, advocacy groups $(n=41)$, and worm diggers $(n=26)$ (see Figure 2).

To further examine our data, we ran matrix coding queries with NVivo to explore relationships between themes, between experts, and between themes and experts. We did not find meaningful or noteworthy patterns through this analysis.

\section{DISCUSSION}

In this final section, we discuss the implications of the results of this work for local news coverage in Maine, as well as the implications for science communication and sustainability science more broadly.

\section{Local Coverage in Maine}

These results carry important implications for local news coverage of environmental risks in Maine. We found that economic, political, environmental, and public health themes were the most common in newspaper coverage of shellfish, while the cultural and technical aspects of shellfish and shellfish management were somewhat rare. The lack of a technical theme is particularly notable. Infrastructural failures, including septic and sewer systems, are one of the key sources of bacterial contamination along the coast (Maine Healthy Beaches, 2013), and it is a source of contamination that can be addressed by Maine residents (e.g., updating their home sewer systems). Increasing the newspaper coverage of the connection between technical and infrastructural contributors to bacterial contamination could in turn inform Maine citizens of the connection and aid in reducing future contamination events that are a result of infrastructural failures.

Regarding expertise, the individuals who are arguably the most affected by shellfish flat closures (shell fishermen and wormers) were the least cited in newspaper coverage. By contrast, government agencies responsible for regulating these coastal resources were cited the most. These results mirror other studies that highlight journalists' significant reliance on government figures and authority sources (Greenberg et al., 1989; Sandman, 1994; Boykoff and Boykoff, 2007). Notably, newspaper articles that did feature clammers, shell fishermen, and wormers tended to include them within the context of policy debates regarding shellfish management and presented them as a sort of dissenting opinion to state regulators. Again, this finding mirrors previous literature on journalistic norms, particularly as they relate to dramatization and personalization (Boykoff and Boykoff, 2007). In Maine, this dynamic could fuel tensions between regulators and those who are most affected by the manner in which shellfish flats are regulated. This dynamic could also reduce the likelihood of shell fishermen and state regulators collaborating with each other on potential solutions to bacterial contamination. In addition, the lack of inclusion of the voices of shell fishermen and wormers in newspaper coverage functions to exclude their perspectives in shaping public dialog and understanding of shellfish-related issues. While these results are not generalizable to news coverage about other environmental risks, they do echo the results of previous work and provide a window into how newspapers in Maine approach coverage of said risks.

\section{Implications for Science Communication and Sustainability Science}

Previous work demonstrates that the news media negotiate public engagement with environmental risks (Coleman, 1993; Allan et al., 2000), that local media play an important role in communicating with the public about risks to the environment and public health (Wakefield and Elliott, 2003), and that local media outlets are often the most trusted source of news (Mitchell et al., 2016). Previous work also demonstrates that newspaper coverage remains an important source of information for the public (McCallum et al., 1991; Driedger, 2007; Gallup, 2017) particularly regarding environmental risks (Sampei and Aoyagi-Usui, 2009). Previous work continues to demonstrate that media play an important role in signaling to the public whose opinion matters regarding environmental risks (Allan et al., 2000) and communicatively constructing expertise more generally (Kuhn and Rennstam, 2016). This study builds off of previous literature by utilizing local newspaper outlets in Maine to understand media coverage of local 
environmental risks-in this case, bacterial contamination-and the ways in which local newspapers communicatively attribute knowledgeability and expertise regarding those risks.

More specifically, this study demonstrates the efficacy of thematic content analysis in understanding how environmental risks are communicated to the public via local newspaper outlets, what individuals or groups are positioned as experts regarding those risks, and how scientific voices are positioned within the context of that expertise. That is, understanding media as an avenue through which expertise is constructed, media content analysis provides an initial list of who the public might assume to be experts on a given topic and how scientists fit into that role. This allows science communication researchers to focus their work on a particular set of experts in studies on expertise and trust for localized environmental risks. Understanding representations of scientific voices is particularly useful within the context of sustainability science, where social scientists analyze media content and public dialog alongside biophysical scientists who study environmental issues. In these instances, in particular, media content analyses could help scientific communities be more active in communicating the science of environmental issues and aid in the call for scientific communities to be more active critics and sources of news (Smith, 2005).

This study also has implications for sustainability science more broadly. This study embraces the idea that mass communication research can aid sustainability science endeavors such as NEST's Safe Beaches and Shellfish Project (Smith et al., 2016) and that content analysis in particular can pinpoint areas for the creation of news media content that advances policy (Dorfman, 2003). We contend that media analyses like the current study can aid sustainability and environmental science efforts in two key ways. First, like the current study, media content analyses can illuminate what voices are being included within public dialog surrounding an environmental issue and what voices are being excluded. This information can then be used to seek out underrepresented voices and provide them participatory space in project trajectory and decision-making for environmental problems, a key goal within sustainability science (Lang et al., 2012) and environmental communication (Hansen, 2011). Second, results from media analyses can be fed back into sustainability science projects to inform media communication strategies surrounding a given environmental issue. These results could include, like the current study, thematic content, citations, and expertise. However, they could also include things like the identification of reporters who cover environmental issues and risks or analyses of representations of relevant stakeholder partners.

\section{Limitations and Future Work}

There are selected limitations to note. First, in an effort to make our sample more manageable, we sampled every fourth article from the total number of articles we collected. It is possible that this sampling frame influenced our results, either in the

\section{REFERENCES}

Ader, C. R. (1995). A longitudinal study of agenda setting for the issue of environmental pollution. J. Mass. Commun. Q. 72, 300-311. doi:10.1177/107769909507200204 frames we found or the sources cited within newspaper coverage. Second, because we were interested in understanding the breadth of themes within our data, we utilized the article as our unit of analysis rather than paragraphs or sentences within the articles. It is possible utilizing whole articles as the unit of analysis influenced our thematic results, such that some themes appear more prevalent than they might have been, had we used a smaller unit of analysis.

There are several opportunities for future work. First, scholars who conduct future research on media coverage of environmental risks should partner with journalists who produce that coverage. Combining content analysis with data from journalists would aid scholarly research in providing holistic feedback regarding overall news coverage and identifying which voices are not being considered part of the public dialog surrounding environmental risks. Journalists can provide scholars with a deeper understanding of news content production regarding environmental risks and can provide a window into the process of finding sources to comment on those risks, something that was missing in the current study. Second, echoing previous literature (e.g., Hansen, 2011), we recommend future work pair media content analyses like the current study with surveys of public perception. This would provide additional context to inform future media coverage of environmental risks and afford both scholars and journalists alike the opportunity to understand and respond to public perceptions. Third, we recommend that future work pair citation analysis like the current study with an examination of how those sources are characterized regarding source credibility. For the current study, we utilized the mere presence of a source in local news coverage as an indicator of expertise - that is, as an attribution of knowledgeability. We did not use the concept of "expertise" as an indicator of actual source credibility, as analyzing attributions of source credibility was not the aim of the current study. We recommend future work embrace this task to add to our understanding of not only what sources media outlets utilize but also the manner in which they characterize those sources in terms of actual source credibility.

\section{AUTHOR CONTRIBUTIONS}

BS developed project details, conducted data analysis, wrote the manuscript. EA aided in the development of project details, conducted data analysis, and edited the manuscript. VS aided in the development of project details, conducted data analysis, and edited the manuscript. LL was a project supervisor, provided feedback throughout the project, principle investigator for funding, and edited the manuscript.

\section{FUNDING}

This work was supported by National Science Foundation award \#IIA-1330691 to Maine EPSCoR at the University of Maine.

Allan, S., Adam, B., and Carter, C. (2000). Environmental Risks and the Media. New York, NY: Psychology Press.

Bell, A. (1994). Media (mis)communication on the science of climate change. Public Underst. Sci. 3, 259-275. doi:10.1088/0963-6625/3/3/002 
Boykoff, M., and Boykoff, J. (2007). Climate change and journalistic norms: a case-study of US mass-media coverage. Geoforum 38, 1190-1204. doi:10.1016/j. geoforum.2007.01.008

Boykoff, M. T. (2011). Who Speaks for the Climate? Making Sense of Media Reporting on Climate Change. Cambridge, England: Cambridge University Press.

Bunderson, S. J., and Barton, M. A. (2010). "Status cues and expertise assessment in groups: how group members size one another up... and why it matters," in Status in Management and Organizations, ed. J. L. Pearce (New York, NY: Cambridge University), 215-237.

Carr, E. S. (2010). Enactments of expertise. Annu. Rev. Anthropol. 39, 17-32. doi:10.1146/annurev.anthro.012809.104948

Cole, A., Langston, A., and Davis, C. (2016). Maine Aquaculture Economic Impact Report. Maine, USA: University of Maine Aquaculture Research Institute. Available at: https://www.maineaquaculture.org/files/2017/01/AquacultureEcon-Report-25ilqf3.pdf (Accessed: September 15, 2017).

Coleman, C. L. (1993). The influence of mass media and interpersonal communication on societal and personal risk judgments. Communic. Res. 20, 611-628. doi:10.1177/009365093020004006

Colgan, C. (2004). The Contribution of Working Waterfronts to the Maine Economy. Maine's Working Waterfront Coalition. Available at: https://www.ceimaine.org/ wp-content/uploads/2014/02/Colgan-Report-Final.pdf (Accessed: September $20,2017)$.

Dorfman, L. (2003). Studying the news on public health: how content analysis supports media advocacy. Am. J. Health Behav. 27, S217-S226. doi:10.5993/ AJHB.27.1.s3.5

Driedger, S. M. (2007). Risk and the media: a comparison of print and televised news stories of a Canadian drinking water risk event. Risk Anal. 27, 775-786. doi:10.1111/j.1539-6924.2007.00922.x

Ednie, A. J., Daigle, J. J., and Leahy, J. E. (2010). Place attachment on the Maine coast: user characteristics and reasons for visiting. J. Park Recreat. Admin. 28. Available at: https://search.proquest.com/docview/1730174454/abstract/5D568BC8912B4BB7PQ/1 (Accessed: September 1, 2017).

Elston, R. A., Hasegawa, H., Humphrey, K. L., Polyak, I. K., and Häse, C. C. (2008). Re-emergence of Vibrio tubiashii in bivalve shellfish aquaculture: severity, environmental drivers, geographic extent and management. Dis. Aquat. Organ. 82, 119-134. doi:10.3354/dao01982

Gallup. (2017). Media Use and Evaluation. Available at: https://news.gallup.com/ poll/1663/Media-Use-Evaluation.aspx (Accessed: August 15, 2017).

Greenberg, M. R., Sachsman, D. B., Sandman, P. M., and Salomone, K. L. (1989). Network evening news coverage of environmental risk. Risk Anal. 9, 119-126. doi:10.1111/j.1539-6924.1989.tb01227.x

Griffin, R. J., and Dunwoody, S. (1997). Community structure and science framing of news about local environmental risks. Sci. Commun. 18, 362-384. doi:10.1177/ 1075547097018004005

Hansen, A. (2011). Communication, media and environment: towards reconnecting research on the production, content and social implications of environmental communication. Int. Commun. Gaz. 73, 7-25. doi:10.1177/1748048510386739

Horst, M. (2013). A field of expertise, the organization, or science itself? Scientists' perception of representing research in public communication. Sci. Commun. 35, 758-779. doi: $10.1177 / 1075547013487513$

Hsieh, H.-F., and Shannon, S. E. (2005). Three approaches to qualitative content analysis. Qual. Health Res. 15, 1277-1288. doi:10.1177/1049732305276687

Huckfeldt, R. (2001). The social communication of political expertise. Am. J. Pol. Sci. 45, 425-438. doi:10.2307/2669350

Jaspers, J. (2014). From unwanted to so-called expertise. Sci. Commun. 36, 570-592. doi:10.1177/1075547014547160

Kuhn, T., and Rennstam, J. (2016). "Expertise as a practical accomplishment among objects and values," in Expertise, Communication, and Organizing, eds J. Treem and P. Leonardi (Oxford, United Kingdom: Oxford University Press), 25-43.

Lang, D. J., Wiek, A., Bergmann, M., Stauffacher, M., Martens, P., Moll, P., et al. (2012). Transdisciplinary research in sustainability science: practice, principles, and challenges. Sustain. Sci. 7, 25-43. doi:10.1007/s11625-011-0149-x

Maine Department of Marine Resources. (2017). Maine Bacterial Closures: Shellfish Pollution Area Inventory With Legal Notices and Maps. Available at: https:// www.maine.gov/dmr/shellfish-sanitation-management/closures/pollution. html (Accessed: August 1, 2017).
Maine Healthy Beaches. (2013). How Are Water-Related Illnesses Spread? Available at: https://www.mainehealthybeaches.org/science.html (Accessed: September $8,2017)$.

Mallin, M. A., Ensign, S. H., McIver, M. R., Shank, G. C., and Fowler, P. K. (2001). "Demographic, landscape, and meteorological factors controlling the microbial pollution of coastal waters," in The Ecology and Etiology of Newly Emerging Marine Diseases. Developments in Hydrobiology, Vol. 159, ed. J. W. Porter (Dordrecht: Springer), 185-193.

McCallum, D. B., Hammond, S. L., and Covello, V. T. (1991). Communicating about environmental risks: how the public uses and perceives information sources. Health Educ. Q. 18, 349-361. doi:10.1177/109019819101800307

McCay, B. J., and Acheson, J. M. (1990). The Question of the Commons: The Culture and Ecology of Communal Resources. Tucson, Arizona: University of Arizona Press.

Mitchell, A., Gottfried, J., Barthel, M., and Shearer, E. (2016). The Modern News Consumer. Washington, DC: Pew Research Center.

Morton, J., Quan, J., Nelson, V., and Albright, K. (2002). Improving communication with U.K. agricultural and related scientific expertise: U.K. NGO perspectives. Sci. Commun. 23, 442-462. doi:10.1177/107554700202300404

Nisbet, M., and Lewenstein, B. (2002). Biotechnology and the American media: the policy process and the elite press, 1970 to 1999 . Sci. Commun. 23, 359-391. doi:10.1177/107554700202300401

Sampei, Y., and Aoyagi-Usui, M. (2009). Mass-media coverage, its influence on public awareness of climate-change issues, and implications for Japan's national campaign to reduce greenhouse gas emissions. Glob. Environ. Change 19, 203-212. doi:10.1016/j.gloenvcha.2008.10.005

Sandman, P. M. (1994). Mass media and environmental risks: seven principles. Risk Health Saf. Environ. 5:251-260.

Shumway, S., and Rodrick, G. (2009). Shellfish Safety and Quality. Cambridge: Woodhead Publishing Limited.

Smith, H., Suldovsky, B., and Lindenfeld, L. (2016). Mass communication research in sustainability science: moving toward an engaged approach to address society's sustainability dilemma. Mass Commun. Soc. 19, 548-565. doi:10.1080/ 15205436.2016 .1167916

Smith, J. (2005). Dangerous news: media decision making about climate change risk. Risk Anal. 25, 1471-1482. doi:10.1111/j.1539-6924.2005.00693.x

Spence, P. R., Lachlan, K. A., and Griffin, D. R. (2007). Crisis communication, race, and natural disasters. J. Black Stud. 37,539-554. doi:10.1177/0021934706296192

Treem, J. W. (2012). Communicating expertise: knowledge performances in professional-service firms. Commun. Monogr. 79, 23-47. doi:10.1080/03637751. 2011.646487

Treem, J. W., and Leonardi, P. M. (2016). Expertise, Communication, and Organizing. Oxford, England: Oxford University Press

Vezzulli, L., Brettar, I., Pezzati, E., Reid, P. C., Colwell, R. R., Höfle, M. G., et al. (2012). Long-term effects of ocean warming on the prokaryotic community: evidence from the vibrios. ISME J. 6, 21-30. doi:10.1038/ismej.2011.89

Wakefield, S. E. L., and Elliott, S. J. (2003). Constructing the news: the role of local newspapers in environmental risk communication. Prof. Geographer 55, 216-226. doi:10.1111/0033-0124.5502009

Wayland, C. (2003). Contextualizing the politics of knowledge: physicians' attitudes toward medicinal plants. Med. Anthropol. Q. 17, 483-500. doi:10.1525/ maq.2003.17.4.483

Conflict of Interest Statement: The authors declare that the research was conducted in the absence of any commercial or financial relationships that could be construed as a potential conflict of interest.

The handling editor declared a past co-authorship with two of the authors, LL and BS.

Copyright $\odot 2018$ Suldovsky, Arbor, Skillin and Lindenfeld. This is an open-access article distributed under the terms of the Creative Commons Attribution License (CC $B Y)$. The use, distribution or reproduction in other forums is permitted, provided the original author(s) and the copyright owner are credited and that the original publication in this journal is cited, in accordance with accepted academic practice. No use, distribution or reproduction is permitted which does not comply with these terms. 